\title{
ANALISIS POTENSI HASIL SAMPING PANEN PERTANIAN TANAMAN PANGAN SEBAGAISUMBER PAKAN ALTERNATIF TERNAK KERBAU DI KABUPATEN PAKPAK BHARAT
}

\author{
Potential Analysis of Agriculture by Product as Source Alternative Feed for \\ Buffalo in Pakpak Bharat
}

\author{
Riyena Talarosa Pohan ${ }^{1}$, Iskandar Sembiring ${ }^{2}$ dan Nevy Diana Hanafi ${ }^{2}$ \\ 1. Mahasiswa Program Studi Peternakan Fakultas Pertanian Universitas SumateraUtara \\ 2. Staf Pengajar Program Studi Peternakan Fakultas Pertanian Universitas Sumatera Utara
}

\begin{abstract}
The land use change and climate limit the availability of forage, which is the principal for feed ruminants. Purpose of this study to analyzes thepotential of harvestfood crops by productas a source ofalternative for buffaloes feedinPakpakBharat. The method used was survey mothod that by selecting 3 subdistrict center of food crops in Pakpak Bharat as the sampling location of crop residu. Crop by product was got by tilled, all the samples was collected in this study were 38 samples, to determine the quality of food crop residue analisis used was proximate analysis. The results showedthe amount production of crops by products based onfreshproduct, dry matterandcrude protein are 84.453,87tons/year,27.497,46 tons/year and1.641,66tons/year respectively.Carrying capacity of food cropby productas analternative feedsource forbuffaloesbydry matter15.044 AU/year, the potential livestock increasing capacity is 13.729 AU/year. The conclusion from this study is in Pakpak Bharat there are 4 types of crop by product can use as an alternative feed for bufalo are rice straw, corn straw, leaves of cassava and and sweat potato leaves.
\end{abstract}

Keywords: Crop by products, fresh, dry matter (DM), crude protein (CP), animal unit (AU), Pakpak Bharat

\begin{abstract}
ABSTRAK
Perubahan fungsi lahan dan iklim membatasi ketersediaan hijauan pakan yang merupakan pakan pokok ternak ruminansia. Penelitian ini menganalisis potensi hasil samping panen pertanian tanaman pangan sebagai sumber pakan alternatif ternak kerbau di Kabupaten Pakpak Bharat. Metode yang digunakan adalah dengan metode survei. Data yang digunakan berupa data primer dan data sekunder. Data primer diperoleh dari instansi terkait sedangkan data sekunder yaitu diperoleh dari pengamatan, yaitu dengan cara memilih 3 Kecamatan sentara tanaman pangan di Kabupaten Pakpak Bharat sebagai lokasi pengambilan sampel hasil samping tanaman pangan. Sampel yang terkumpul dalam penelitian adalah 38 sampel.Untuk mengetahui kualitas hasil samping panen tanaman pangan maka dilakukan analisis proksimat di Laboratorium Nutrisi dan Makanan Ternak. Hasil penelitian menunjukkan jumlah produksi hasil samping panen pertanian tanaman pangan berdasarkan bahan segar, bahan kering dan protein kasar masing-masing 84.453,87 ton/thn, 27.497,46 ton/thn dan 1.641,66 ton/thn dengan daya dukung BK adalah 15.044ST/thn dengan kapasitas peningkatan populasi ternak adalah 13.729 ST/thn.Kesimpulan dari penelitian ini adalah di Kabupaten Pakpak Bharat terdapat 4 jenis hasil samping panen tanaman pangan yang potensial diigunakan sebagai sumber pakan alternatif ternak kerbau antara lain jerami padi, jerami jagung, daun ubi kayu dan daun ubi jalar.
\end{abstract}

Kata kunci: Hasil samping panen pertanian tanaman pangan, daya tampung, segar, bahan kering (BK), protein kasar (PK), satuan ternak (ST) 


\section{PENDAHULUAN}

Pengembangan usaha peternakan memiliki prospek yang semakin cerah dimasa depan, karena permintaan terhadap jenis pangan yang berasal dari ternak semakin meningkat seiring dengan meningkatnya jumlah penduduk.Untuk mengembangkan usaha peternakan, khususnya ternak ruminansia, sangat dibutuhkan lahan yang luas untuk pengadaan hijauan pakan ternak. Beberapa hal yang menghambat tersedianya hijauan pakan ternak yaitu terjadinya perubahan fungsi lahan yang sebelumnya sebagai sumber hijauan pakan ternak menjadi lahan pemukiman, lahan untuk tanaman pangan, tanaman perkebunan dan industri, ketersediaan hijauan pakan ternak juga sangat dipengaruhi oleh musim (iklim), dimana pada musim kemarau jumlah hijauan pakan ternak sangat terbatas sedangkan pada musim hujan sangat melimpah.

Kurang tersedianya pakan hijauan merupakan salah satu kendala dalam pengembangan usaha peternakan, khususnya ternak ruminansia. Untuk mengatasi kekurangan hijauan pakan ternak, salah satu solusi yang dapat dilakukan adalah dengan pemanfaatan hasil samping panen pertanian sebagai sumber pakan alternatif pengganti hijauan.

Djayanegara dan Sitorus (1983) menyatakan bahwa sebagian besar limbah pertanian dapat dimanfaatkan sebagai makanan ternak. Walaupun demikian masih banyak limbah ini yang belum dimanfaatkan. Hambatan yang sering dialami adalah kualitas yang rendah, kurang disukai ternak dan produksinya berfluktuasi.

Kabupaten Pakpak Bharat diperkirakan mempunyai potensi untuk pengembangan ternak ruminansia khususnya ternak kerbau, karena memiliki hasil samping panen pertanian tanaman pangan yang melimpah yang dapat dimanfaatkan sebagai pakan ternak alternatif pengganti hijauan. Berdasarkan data hasil survey Badan Pusat Statistik Kabupaten Pakpak Bharat (2012)luas panen tanaman padi mencapai 6.902 ha, luas panen tanaman jagung mencapai 2.243 ha, luas panen tanaman ubi jalar mencapai 94 ha, dan luas panen tanaman ubi kayu mencapai 103 ha.

Tujuan dari penelitian ini menghitung produksi hasil samping panen pertanian tanaman pangan berdaasarkan kualitas dan kuantitas yang dapat dimanfaatkan sebagai sumber pakan alternatif terhadap kapasitas peningkatan ternak kerbau di Kabupaten Pakpak Bharat.

\section{BAHAN DAN METODE PENELITIAN}

\section{Waktu dan Tempat Penelitian}

Penelitian ini dilaksanakan pada bulan Mei 2014 sampai dengan bulan Agustus 2014 di beberapa Kecamatan di Kabupaten Pakpak Bharat, Provinsi Sumatera Utara. Pengambilan data 
atau sampel dilakukan pada saat terjadi panen tanaman pangan. Analisis laboratorium (proksimat) sampel pakan dilaksanakan di Laboratorium Bahan Pakan Ternak, Fakultas Pertanian Universitas Sumatera Utara, Medan setelah dilakukan pengambilan sampel tanaman pangan.

\section{Data Kecamatan dan Desa Tempat Penelitian}

Berdasarkan data statistik administrasi pemerintahan Kabupaten Pakpak Bharat terbagi atas 8 Kecamatan. Dalam penelitian ini kecamatan terpilih yang menjadi lokasi penelitian diambil 30\% dari jumlah seluruh Kecamatan yang ada di Kabupaten Pakpak Bharat. Penentuan Kecamatan terpilih dilakukan secara sengaja (purposive sampling). Menurut Sugiyono (2008) purposive sampling adalah teknik pengambilan sampel/sumber data dengan pertimbangan tertentu.Kecamatan terpilih yang menjadi lokasi dalam penelitian ini adalah Kecamatan Kerajaan, Kecamatan Tinada dan Kecamatan Siempat Rube dengan pertimbangan bahwa Kecamatan terpilih memiliki luas areal tanam tanaman pangan yang paling luas di Kabupaten Pakpak Bharat dan masing-masing Kecamatan terpilih merupakan sentral tanaman pangan.

Setiap kecamatan diambil sampel desa sebanyak 40\% (Gay, 1976) dan disetiap desa diambil responden petani dan peternak sebanyak 30\% dari jumlah penduduk (KK) setiap Desa. Pemilihan Desa yang menjadi lokasi penelitian di tentukan dengan cara melihat Desa-desa sentral pertanian tanaman pangan yang terdapat di masing-masing Kecamatan. Yang menjadi Desa terpilih dan jumlah responden dalam penelitian ini adalah dapat dilihat dalam Tabel 1.

\section{Metode Pengumpulan Data}

Data yang dikumpulkan dalam penelitian ini berupa data primer dan data sekunder. Data sekunder yang berhubungan dengan tujuan penelitian ini diperoleh dari instansi terkait yaitu Dinas Pertanian dan Perkebunan Kabupaten Pakpak Bharat, Balai Penyuluh Pertanian Kabupaten Pakpak Bharat, Kantor Kecamatan, dan Kantor Badan Pusat Statistik Kabupaten Pakpak Bharat. Data Primer diperoleh dengan cara melakukan pengamatan di Desa terpilih yang menjadi lokasi penelitian.

\section{Pelaksanaan Penelitian}

\section{Survei Produksi Hasil Samping Panen Pertanian Tanaman Pangan}

Produksi hasil samping panen pertanian tanaman pangan diketahui dari hasil survey pada lokasi yang telah ditentukan pada setiap komoditi pertanian. Produksi hasil samping panen pertanian tanaman pangan diketahui dengan menggunakan cuplikan (ubinan) untuk 
setiap komoditi pertanian yaitu padi, jagung, ubi kayu dan ubi jalar dengan ukuran 1 x $1 \mathrm{~m}$ dan dilakukan 5 kali pencuplikan (ubinan) dalam $1 \mathrm{Ha}$, dengan tujuan untuk mengetahui berat ratarata hasil samping panen tanaman pangan.

Tabel 1. Kecamatan, Desa dan jumlah responden masing masing Desa

\begin{tabular}{llc}
\hline Kecamatan & Desa Terpilih & Jumlah Responden (Orang) \\
\hline Kerajaan & Majanggut I & 38 \\
& Perpulungen & 94 \\
& Kuta Dame & 138 \\
Tinada & Sukarame & 100 \\
& Tinada & 72 \\
\multirow{2}{*}{ Siempat Rube } & Silima Kuta & 50 \\
& Prongil & 54 \\
& Siempat Rube I & 55 \\
& Siempat Rube IV & 61 \\
Total Responden & Kuta Jungak & 31 \\
\hline
\end{tabular}

Setiap komoditi pertanian (padi, jagung, ubi kayu dan ubi jalar) yang dikumpulkan dengan pengubinan, limbahnya dikumpul dan ditimbang bobot segarnya sehingga diketahui produksi masing-masing hasil samping panen pertanian tanaman pangan tiap komoditi $\left(\mathrm{kg} / 1 \mathrm{~m}^{2}\right)$.

Kualitas hasil samping panen pertanian tanaman pangan yang telah dikumpulkan diketahui melalui hasil uji proksimat berdasarkan AOAC (1990)Parameter yang dianalisis adalah bahan kering (BK), kadar air, protein kasar (PK), lemak kasar (LK), dan serat kasar (SK) (Sudarmadji et al, 1984)

\section{Analisis Data}

\section{a. Produksi Hasil Samping Panen Pertanian Tanaman Pangan}

Produksi hasil samping panen pertanian tanaman pangan dihitung berdasarkan produksi segar, produksi bahan kering (BK) dan produksi protein kasar (PK). Produksi setiap hasil samping panen pertanian tanaman pangan pertanian masing-masing komodity dihitung berdasarkan data luas areal panen (ha) di suatu wilayah/panen, dilakukan perhitungan sebagai berikut :

- Total produksi segar (ton) = produksi segar (ton/ha) $\mathrm{x}$ luas panen (ha)

- Total produksi BK (ton) = luas panen (ha) x kandungan BK (\%)

- Total produksi PK (ton) = total produksi BK x kandungan PK (\%) 


\section{b. Daya Dukung Hasil Samping Panen Pertanian tanaman pangan (DDHSP)}

Daya dukung hasil samping panen pertanian tanaman pangan (DDHSP) adalah kemampuan suatu wilayah menghasilkan pakan berupa hasil samping panen pertanian tanaman pangan tanpa melalui pengolahan. Menghitung daya dukung hasil samping pertanian terhadap $1 \mathrm{ST}(1 \mathrm{ST}=350 \mathrm{~kg}$ ), ruminansia rata-rata membutuhkan hijauan segar setiap harinya $10 \%$ dari bobot badan yaitu $35 \mathrm{Kg} / \mathrm{hari}$, kebutuhan BK $3 \%$ dari bobot badan yaitu 10,5 $\mathrm{Kg} / \mathrm{hari}$. Kebutuhan hijauan pakan ternak ruminansia dalam setahun dihitung berdasarkan produksi segar, BK dan PK. Asumsi yang digunakan yaitu 1 ST rata-rata mampu mengkonsumsi jerami segar sebanyak $7 \mathrm{~kg} / \mathrm{h}$ ari atau $2.555 \mathrm{~kg} /$ tahun (Haryanto et al., 2002), jerami kering $5 \mathrm{~kg} / \mathrm{hari}$ atau 1,825 ton/tahun (Neumann dan Lusby, 1986) serta kebutuhan Bahan kering (BK) 6,25 $\mathrm{kg} / \mathrm{hari}$ (NRC, 1984). Daya dukung hasil samping panen pertanian tanaman pangan dihitung berdasarkan rumus sebagai berikut:

DDHSP berdasarkan berat segar = produksi segar (ton/thn)/ kebutuhan segar $1 \mathrm{ST}$ (ton/thn).

$\checkmark$ DDHSP berdasarkan BK(ton/thn) $=$ produksi BK (ton/thn)/ kebutuhan BK 1 ST (ton/thn).

$\checkmark$ DDHSP berdasarkan PK (ton/thn) = produksi PK (ton/thn)/ kebutuhan PK 1 ST (ton/thn) (Syamsu, 2006).

\section{Kapasitas Peningkatan Ternak}

Nilai kapasitas peningkatan populasi ternak kerbau dihitung sebagai selisih antara daya dukung pakan yang berasal dari hasil samping panen pertanian tanaman pangan dengan jumlah ternak kerbau yang ada di wilayah tersebut. Satuan ternak ruminansia terdapat pada Tabel 2.

Tabel 2. Standar satuan ternak ruminansia.

\begin{tabular}{lll}
\hline Jenis Ternak & Kelompok Umur & Satuan Ternak \\
\hline Kerbau & Dewasa & 1,0 \\
& Muda & 0,50 \\
\multirow{3}{*}{ Sapi } & Anak & 0,25 \\
& Dewasa & 1,00 \\
& Muda & 0,50 \\
Kambing/ Domba & Anak & 0,25 \\
& Dewasa & 0,14 \\
& Muda & 0,07 \\
& Anak & 0,035 \\
\hline
\end{tabular}

Sumber :Febrianadan Liana (2008) 


\section{HASIL DAN PEMBAHASAN}

\section{Gambaran Umum Lokasi Penelitian}

Kecamatan Siempat Rube merupakan salah satu Kecamatan hasil pemekaran dari Kecamatan Kerajaan dengan luas wilayah 82,36 $\mathrm{Km}^{2}$. Kecamatan Siempat Rube terdiri dari 6 Desa dan 22 dusun. Kecamatan Siempat Rube terletak dibagian tengah Kabupaten Pakpak Bharat dengan jarak ke Ibukota Kabupaten (Kota Salak) adalah 9,5 Km. Hasil pertanian yang merupakan sumber mata pencaharian masyarakat pada umumnya adalah padi sawah, padi ladang dan tanaman palawija seperti: jagung, ubi kayu, ubi jalar dan kacang tanah serta tanaman keras seperti kayu manis, kemiri, gambir, jengkol dan petai.

Kecamatan Tinada dengan ibukotanya Tinada adalah salah satu Kecamatan diantara 8 Kecamatan di daerah hukum Kabupaten Pakpak Bharat, dengan luas wilayah 1.218,30 Km² yang terdiri dari 6 Desa. Kecamatan ini terletak di bagian tengah Kabupaten Pakpak Bharat, dengan jarak ke ibu kota Kabupaten Pakpak Bharat (Kota Salak) \pm 8 Km. Kecamatan Kerajaan dengan Ibu kotanya Sukaramai adalah salah satu Kecamatan diantara 8 Kecamatan di daerah hukum Kabupaten Pakpak Bharat, Provinsi Sumatera Utara dengan luas wilayah 147,61 km2 yang terdiri dari 10 Desa. Kecamatan ini terletak di bagian tengah Kabupaten Pakpak Bharat, dengan jarak dari Kecamatan Salak (Ibukota Kabupaten Pakpak Bharat) ke Sukaramai (Ibukota Kecamatan Kerajaan) $18 \mathrm{Km}$. Kecamatan Kerajaan memiliki lahannya cukup luas dan subur sehingga sebagian besar penduduknya bekerja di sektor pertanian, perkebunan, peternakan, dan sebagian kecil hidup dari usaha perdagangan, industri, penggalian batu/pasir, buruh, jasa Pemerintah/PNS dan TNI/Polri.

\section{Produksi Segar Hasil Samping Panen Pertanian Tanaman Pangan}

Jumlah produksi segar (Tabel 4) hasil samping panen pertanian tanaman pangan di setiap desa paling banyak dihasilkan dari pertanian tanaman padi (jerami padi) dengan produksi total jerami padi yaitu sebanyak 51.395,91 ton, dengan produksi tertinggi yaitu sebanyak 5.877,90 ton yang terdapat di Desa Siempat Rube I, tingginya produksi jerami padi pada Desa tersebut dipengaruhi oleh luas areal pertanian masing-masing Desa seperti terlihat pada Tabel 3 , hal ini sesuai dengan pernyataan Syamsu (2006) yang menyatakan bahwa tingginya produksi limbah tanaman pangan pada suatu daerah dipengaruhi oleh luas areal panen tanaman pangan yang tinggi khususnya areal panen padi sehingga menghasilkan jerami padi yang lebih banyak dan akhirnya berpengaruh kepada tingginya total produksi bahan kering limbah tanaman pangan. 
Tabel 3. Luas areal panen tanaman pangan di Kabupaten Pakpak Bharat.

\begin{tabular}{|c|c|c|c|c|c|c|}
\hline \multirow[t]{2}{*}{ Kecamatan } & \multirow[t]{2}{*}{ Desa } & \multicolumn{4}{|c|}{$\begin{array}{c}\text { Luas areal panen tanaman pangan } \\
\text { (ha/tahun) }\end{array}$} & \multirow[t]{2}{*}{$\begin{array}{l}\text { Total luas } \\
\text { panen (ha) }\end{array}$} \\
\hline & & Padi & Jagung & $\begin{array}{c}\text { Ubi } \\
\text { kayu }\end{array}$ & $\begin{array}{l}\text { Ubi } \\
\text { jalar }\end{array}$ & \\
\hline \multirow[t]{10}{*}{ Kerajaan } & Majanggut I & 32,00 & 2,00 & 0,00 & 0,00 & 34,00 \\
\hline & Majanggut I & 113,00 & 24,00 & 0,80 & 0,00 & 137,80 \\
\hline & Pardomuan & 80,00 & 12,00 & 1,60 & 0,00 & 93,60 \\
\hline & Parpulungan & 236,50 & 83,00 & 2,30 & 0,00 & 321,80 \\
\hline & Kuta Saga & 82,00 & 38,00 & 2,10 & 2,00 & 124,10 \\
\hline & Kuta Dame & 300,20 & 84,00 & 3,10 & 0,00 & 387,30 \\
\hline & Kuta Meriah & 69,20 & 24,00 & 1,30 & 0,00 & 94,50 \\
\hline & Sukarame & 89,50 & 43,00 & 2,50 & 1,00 & 136,00 \\
\hline & Surung Mersada & 75,00 & 16,00 & 1,00 & 0,00 & 92,00 \\
\hline & Perduhapen & 36,00 & 12,00 & 1,30 & 0,00 & 49,30 \\
\hline \multirow[t]{6}{*}{ Tinada } & Mahala & 78,51 & 32,07 & 1,95 & 0,00 & 112,53 \\
\hline & Tinada & 119,36 & 80,03 & 3,90 & 3,81 & 207,10 \\
\hline & Silima Kuta & 211,07 & 97,67 & 2,60 & 1,90 & 313,24 \\
\hline & Kuta Babo & 53,10 & 78,83 & 1,30 & 0,47 & 133,70 \\
\hline & Prongil & 157,71 & 44,82 & 2,60 & 2,85 & 207,98 \\
\hline & Buluh Tellang & 84,16 & 83,23 & 0,65 & 0,95 & 168,99 \\
\hline \multirow{6}{*}{$\begin{array}{l}\text { Siempat } \\
\text { Rube }\end{array}$} & Siempat Rube I & 311,00 & 109,00 & 2,30 & 2,10 & 424,20 \\
\hline & Siempat Rube II & 124,00 & 70,00 & 3,00 & 3,20 & 200,20 \\
\hline & Mungkur & 104,00 & 43,00 & 1,50 & 2,10 & 150,60 \\
\hline & Siempat Rube IV & 159,00 & 78,00 & 3,70 & 4,30 & 245,00 \\
\hline & Kuta Jungak & 149,00 & 53,00 & 3,00 & 2,20 & 207,20 \\
\hline & Traju & 902,00 & 392,00 & 15,00 & 15,00 & $1.324,00$ \\
\hline
\end{tabular}

Sumber : BPS Pakpak Bharat, 2013

\section{Produksi Bahan Kering (BK) Hasil Samping Panen Pertanian Tanaman Pangan}

Ahmad (2010) menyatakan bahwa perbedaan jumlah produksi bahan kering limbah tanaman pangan dapat disebabkan pada perbedaan pola tanam, jarak tanam, kondisi iklim, kesuburan tanah, dan pengairan lahan. Hasil pengamatan di lapangan bahwa pola tanam monokultur akan menghasilkan produksi yang lebih besar dibandingkan pola tanam tumpang sari, jarak tanam yang lebih rapat akan lebih banyak menghasilkan dibandingkan jarak tanam yang lebih jarang.

Hasil analisis proksimat yang telah dilakukan di Laboratorium Nutrisi dan Makanan Ternak Fakultas Pertanian diperoleh hasil bahan kandungan BK jerami padi adalah $36 \%$, kandungan BK Jerami jagung $48 \%$, kandungan BK daun ubi kayu sebesar 38,6 \% dan kandungan BK daun ubi jalar sebesar 50,4\%. 
Produksi total BK dari hasil samping pertanian tanaman pangan yang terdapat di Kabupaten Pakpak Bharatyaitu sebesar 84.453,87ton dengan produksi terbanyak berasal dari jerami padi yaitu sebesar51.395,91ton. Besarnya hasil samping panen berupa jerami padi yang terdapat di Kabupaten Pakpak Bharat sangat ditentukan oleh luas areal panen pertanaman padi seperti terlihat pada Tabel 1. Hal ini sesuai dengan pernyataan Syamsu (2006) yang menyatakan bahwa tingginya produksi limbah tanaman pangan pada suatu daerah dipengaruhi oleh luas areal panen tanaman pangan yang tinggi khususnya areal panen padi sehingga menghasilkan jerami padi yang lebih banyak dan akhirnya berpengaruh kepada tingginya total produksi bahan kering limbah tanaman pangan.

Tabel 4. Produksi segar hasil samping tanaman pangan di Kabupaten Pakpak Bharat

\begin{tabular}{|c|c|c|c|c|c|c|}
\hline \multirow[b]{2}{*}{ Kecamatan } & \multirow[b]{2}{*}{ Desa } & \multicolumn{4}{|c|}{ Produksi segar (ton/thn) } & \multirow{2}{*}{$\begin{array}{c}\text { Total } \\
\text { Produksi } \\
\text { (ton/thn) }\end{array}$} \\
\hline & & $\begin{array}{c}\text { Jerami } \\
\text { padi }\end{array}$ & $\begin{array}{l}\text { Jerami } \\
\text { jagung }\end{array}$ & $\begin{array}{c}\text { Daun ubi } \\
\text { kayu }\end{array}$ & $\begin{array}{c}\text { Daun ubi } \\
\text { jalar }\end{array}$ & \\
\hline \multirow[t]{10}{*}{ Kerajaan } & Majanggut II & 608,80 & 56,00 & 0,00 & 0,00 & 660,80 \\
\hline & Majanggut I & $2.135,70$ & 672,00 & 11,20 & 0,00 & $2.818,90$ \\
\hline & Pardomuan & $1.512,00$ & 336,00 & 22,40 & 0,00 & $1.870,40$ \\
\hline & Parpulungan & $4.469,85$ & $2.324,00$ & 32,20 & 0,00 & $6.826,05$ \\
\hline & Kuta Saga & $1.549,80$ & $1.064,00$ & 29,40 & 24,00 & $2.667,20$ \\
\hline & Kuta Dame & $5.673,78$ & $2.352,00$ & 43,40 & 0,00 & $8.069,18$ \\
\hline & Kuta Meriah & $1.307,88$ & 672,00 & 18,20 & 0,00 & $1.998,08$ \\
\hline & Sukarame & $1.692,50$ & $1.204,00$ & 35,00 & 12,00 & $2.943,50$ \\
\hline & Surung Mersada & $1.417,50$ & 448,00 & 14,00 & 0,00 & $1.879,50$ \\
\hline & Perduhapen & 680,40 & 336,00 & 18,20 & 0,00 & $1.034,60$ \\
\hline \multirow[t]{6}{*}{ Tinada } & Mahala & $1.483,84$ & 897,96 & 27,30 & 0,00 & $2.409,10$ \\
\hline & Tinada & $2.255,90$ & $2.240,84$ & 54,60 & 45,72 & $4.597,06$ \\
\hline & Silima Kuta & $3.989,22$ & $2.734,76$ & 36,40 & 22,80 & $6.783,18$ \\
\hline & Kuta Babo & $1.003,59$ & $2.207,24$ & 18,20 & 5,64 & $3.234,67$ \\
\hline & Prongil & $2.980,72$ & $1.254,96$ & 36,40 & 34,20 & $4.306,28$ \\
\hline & Buluh Tellang & $1.590,62$ & $2.330,44$ & 9,10 & 11,40 & $3.941,56$ \\
\hline \multirow{6}{*}{$\begin{array}{l}\text { Siempat } \\
\text { Rube }\end{array}$} & Siempat Rube I & $5.877,90$ & $3.052,00$ & 32,20 & 25,20 & $8.987,30$ \\
\hline & Siempat Rube II & $2.343,60$ & $1.960,00$ & 42,00 & 38,40 & $4.384,00$ \\
\hline & Mungkur & $1.965,60$ & $1.204,00$ & 21,00 & 25,20 & $3.215,80$ \\
\hline & Siempat Rube IV & $3.005,10$ & $2.184,00$ & 51,80 & 51,60 & $5.292,50$ \\
\hline & Kuta Jungak & $2.816,10$ & $1.484,00$ & 42,00 & 26,40 & $4.368,50$ \\
\hline & Traju & $1.039,50$ & $1.092,00$ & 21,00 & 13,20 & $2.165,70$ \\
\hline \multicolumn{2}{|c|}{ Total Produksi (ton/thn) } & $51.395,91$ & $32.106,20$ & 616,00 & 335,76 & $84.453,87$ \\
\hline
\end{tabular}

Sumber : Data primer hasilpenelitian.

Daya Dukung Hasil Samping Panen Pertanian Tanaman Pangan Berdasarkan Produksi BK.

Daya dukung hasil samping panen pertanian tanaman pangan berdasarkan produksi BK diperoleh dari perbandingan antara produksi BK dengan kebutuhan BK ternak kerbau dalam 1 satuan ternak (ST ). Rata-rata daya dukung hasil samping panen pertanian tanaman 
pangan tertinggi berada pada Kecamatan Siempat Rube dengan daya dukung sebesar 1.929,25 ST (45,73 \%) selanjutnya di ikuti oleh Kecamatan Tinada Sebesar 1.753,04 ST $(41,55 \%)$ dan terakhir adalah Kecamatan Kerajaan dengan rata-rata daya dukung sebesar 535,81 ST $(12,70 \%)$. Besarnya daya dukung yang terdapat pada masing-masing Kecamatan dipengaruhi oleh luas areal tanam pertanian tanaman pangan yang terdapat pada tiap Kecamatan yang berpengaruh terhadap produksi hasilsamping panen pertanian tanaman pangan yang terdapat pada masing-masing Kecamatan. Hal ini sejalan dengan produksi segar hasil samping panen tanaman pangan yang terdapat di Kabupaten Pakpak Bharat.

\section{Kapasitas Peningkatan Ternak}

Nilai kapasitas peningkatan populasi ternak kerbau di dihitung sebagai selisih antara daya dukung pakan hasil samping panen pertanian tanaman pangan dengan jumlah ternak kerbau yang ada.

Tabel 5. Produksi bahan kering (BK) masing-masing hasil samping pertania tanaman pangan

\begin{tabular}{|c|c|c|c|c|c|c|}
\hline \multirow[b]{2}{*}{ Kecamatan } & \multirow[b]{2}{*}{ Desa } & \multicolumn{4}{|c|}{ Produksi berdasarkan BK (ton/thn) } & \multirow{2}{*}{$\begin{array}{c}\text { Total } \\
\text { Produksi } \\
\text { (ton/thn) }\end{array}$} \\
\hline & & $\begin{array}{c}\text { Jerami } \\
\text { padi }\end{array}$ & $\begin{array}{l}\text { Jerami } \\
\text { jagung }\end{array}$ & $\begin{array}{l}\text { D. Ubi } \\
\text { kayu }\end{array}$ & $\begin{array}{c}\text { D. Ubi } \\
\text { jalar }\end{array}$ & \\
\hline \multirow[t]{10}{*}{ Kerajaan } & Majanggut II & 217,73 & 26,88 & 0,00 & 0,00 & 107,24 \\
\hline & Majanggut I & 768,85 & 322,56 & 4,26 & 0,00 & $1.095,73$ \\
\hline & Pardomuan & 544,32 & 161,28 & 8,51 & 0,00 & 714,11 \\
\hline & Parpulungan & $1.609,15$ & $1.115,52$ & 12,42 & 0,00 & $2.736,90$ \\
\hline & Kuta Saga & 557,93 & 510,72 & 11,17 & 12,00 & $1.091,82$ \\
\hline & Kuta Dame & $2.042,56$ & $1.128,96$ & 16,49 & 0,00 & $3.188,01$ \\
\hline & Kuta Meriah & 470,84 & 322,56 & 6,92 & 0,00 & 800,31 \\
\hline & Sukarame & 609,30 & 577,92 & 13,30 & 6,00 & $1.206,52$ \\
\hline & Surung Mersada & 510,30 & 215,04 & 5,32 & 0,00 & 730,66 \\
\hline & Perduhapen & 244,94 & 161,28 & 6,92 & 0,00 & 413,14 \\
\hline \multirow{6}{*}{ Tinada } & Mahala & 534,18 & 431,02 & 10,37 & 0,00 & 975,58 \\
\hline & Tinada & 812,13 & $1.075,60$ & 20,75 & 22,86 & $1.931,34$ \\
\hline & Silima Kuta & $1.436,12$ & $1.312,68$ & 13,83 & 11,40 & $2.774,04$ \\
\hline & Kuta Babo & 361,29 & $1.059,48$ & 6,92 & 17,10 & $1.430,50$ \\
\hline & Prongil & $1.073,06$ & 602,38 & 13,83 & 17,10 & $1.706,37$ \\
\hline & Buluh Tellang & 572,62 & $1.118,61$ & 3,46 & 5,70 & 1700,39 \\
\hline Siempat & Siempat Rube I & $2.116,04$ & $1.464,96$ & 12,42 & 12,60 & $3.605,84$ \\
\hline \multirow[t]{5}{*}{ Rube } & Siempat Rube II & 843,70 & 940,80 & 15,96 & 19,20 & $1.819,66$ \\
\hline & Mungkur & 707,62 & 577,92 & 7,98 & 12,60 & $1.306,12$ \\
\hline & Siempat Rube IV & $1.081,84$ & $1.048,32$ & 19,98 & 25,80 & $2.175,64$ \\
\hline & Kuta Jungak & $1.013,80$ & 712,32 & 15,96 & 13,20 & $1.755,28$ \\
\hline & Traju & 374,22 & 524,16 & 7,98 & 6,60 & 912,96 \\
\hline \multicolumn{2}{|c|}{ Total Produksi (ton/thn) } & $11.684,52$ & $15.410,98$ & 234,08 & 167,88 & $27.497,46$ \\
\hline
\end{tabular}

Sumber : Data primer hasilpenelitian. 
Tabel 6. Daya Dukung Hasil Samping Panen Pertanian Tanaman Pangan (DDHSP) dan Kapasitas Peningkatan Ternak ruminansia di Kabupaten Pakpak Bharat

\begin{tabular}{|c|c|c|c|c|c|c|c|}
\hline \multirow[b]{2}{*}{ Kecamatan } & \multirow[b]{2}{*}{ Desa } & \multicolumn{3}{|c|}{$\begin{array}{c}\text { Jenis Ternak Ruminansia } \\
\text { (ST) }\end{array}$} & \multirow[t]{2}{*}{$\begin{array}{l}\text { Jumlah } \\
\text { (ST) }\end{array}$} & \multirow{2}{*}{$\begin{array}{c}\text { Total } \\
\text { DDHSP } \\
\text { BK (ST) }\end{array}$} & \multirow{2}{*}{$\begin{array}{c}\text { Kapasitas } \\
\text { Peningkatan } \\
\text { Ternak (ST) }\end{array}$} \\
\hline & & Sapi & Kerbau & Kambing & & & \\
\hline \multirow{9}{*}{ Kerajaan } & Majanggut II & 0,00 & 0,00 & 0,00 & 0,00 & 107,24 & 107,24 \\
\hline & Majanggut I & 5,00 & 86,00 & 6,00 & 97,00 & 480,35 & 383,35 \\
\hline & Pardomuan & 0,00 & 18,00 & 0,50 & 18,50 & 313,07 & 294,35 \\
\hline & Parpulungan & 32,00 & 173,00 & 5,85 & 210,85 & $1.199,87$ & 989,02 \\
\hline & Kuta Saga & 8,00 & 79,00 & 3,28 & 90,28 & 478,66 & 388,38 \\
\hline & Kuta Dame & 5,00 & 114,00 & 6,40 & 125,40 & $1.397,64$ & $1.271,24$ \\
\hline & Kuta Meriah & 26,00 & 112,00 & 3,71 & 141,71 & 350,86 & 209,15 \\
\hline & Sukarame & 18,00 & 91,00 & 8,28 & 117,28 & 528,94 & 411,66 \\
\hline & Surung Mersada & 4,00 & 11,00 & 8,71 & 23,71 & 320,32 & 296,61 \\
\hline \multirow{6}{*}{ Tinada } & Perd & 0,00 & 15,00 & 3,00 & 18,00 & 181,12 & 163,12 \\
\hline & Mahala & 0,00 & 107,00 & 11,71 & 118,71 & 427,70 & 308,99 \\
\hline & Tinada & 0,00 & 36,00 & 0,00 & 36,00 & 846,71 & 810,71 \\
\hline & Silima Kuta & 0,00 & 38,00 & 0,00 & 38,00 & $1.216,15$ & $1.178,15$ \\
\hline & Kuta Babo & 0,00 & 10,00 & 0,00 & 10,00 & 627,14 & 617,14 \\
\hline & Prongil & 0,00 & 36,00 & 0,00 & 36,00 & 748,08 & 7712,08 \\
\hline \multirow{7}{*}{$\begin{array}{l}\text { Siempat } \\
\text { Rube }\end{array}$} & Buluh Tellang & 17,00 & 29,00 & 0,00 & 46,00 & 745,46 & 699,46 \\
\hline & Siempat Rube I & 0,00 & 24,00 & 2,80 & 26,80 & $1.580,82$ & $1.554,02$ \\
\hline & Siempat Rube II & 8,00 & 46,00 & 2,00 & 56,00 & 797,74 & 741,74 \\
\hline & $\begin{array}{l}\text { Mungkur } \\
\text { Siempat Rube }\end{array}$ & 0,00 & 15,00 & 1,71 & 16,71 & 572,61 & 555,90 \\
\hline & IV & 0,00 & 23,00 & 2,14 & 25,14 & 953,81 & 928,67 \\
\hline & Kuta Jungak & 0,00 & 38,00 & 1,42 & 39,42 & 769,52 & 730,10 \\
\hline & Traju & 0,00 & 22,00 & 0,85 & 22,85 & 400,25 & 377,40 \\
\hline Total ST & & 123,00 & $.123,00$ & 68,34 & $1.314,34$ & $15.044,04$ & $13.729,68$ \\
\hline
\end{tabular}

Sumber : Data primer hasilpenelitian.

Berdasarkan produksi bahan kering (BK) maka kapasitaspeningkatan jumlah ternak yang terdapat di Kabupaten Pakpak Bharat adalah sebesar 13.729,68 ST. Hal ini menunjukkan bahwa di Kabupaten Pakpak Bharat masih memungkinkan untuk penambahan populasi ternak kerbau seperti terlihat pada Tabel 6.

\section{KESIMPULAN}

Kabupaten Pakpak Bharat memiliki 4 jenis hasil samping panen pertanian tanaman pangan yang potensial di gunakan sebagai sumber pakan alternatif ternak kerbau diantaranya jerami padi, jerami jagung, daun ubi kayu dan daun ubi jalar. Berdasarkan BK mampu menampung ternak sebesar 15.044,04 ST. Besarnya potensi hasil samping panen 
pertanian tanaman pangan di Kabupaten Pakpak Bharat diperlukan kerjasama antara peternak, petani, pemerintah, pihak swasta dan akademisi dalam optimalisasi pemanfaatan hasil samping panen tanaman pangan sebagai sumber pakan alternatif ternak kerbau.

\section{DAFTAR PUSTAKA}

Ahmad, C. 2010. Potensi Ketersediaan Limbah Tanaman Pangan dan Hasil SampinganIndustri Pertanian Sebagai Pakan Ternak di Kabupaten Tulang Bawang Barat Provinsi Lampung. Skripsi. IPB. Bogor.

Badan Pusat Statistik Kabupaten Pakpak Bharat. 2012. Pakpak Bharat Dalam angka.

Badan Pusat Statistik Kabupaten Pakpak Bharat. 2013. Kecamatan Kerajaan dalam angka.

Badan Pusat Statistik Kabupaten Pakpak Bharat. 2013. Kecamatan Siempat Rube dalam angka.

Badan Pusat Statistik Kabupaten Pakpak Bharat. 2013. Kecamatan Tinada dalam angka.

Badan Pusat Statistik Kabupaten Pakpak Bharat. 2014. // http : //pakpakbharatkab.bps.go.id//) diakses pada 13 Maret 2014.

Badan Pusat Statistik Kabupaten Pakpak Bharat. 2013. Pakpak Bharat Dalam angka.

Febriana, D. dan Liana, M., 2008, Pemanfaatan Limbah PertanianSebagai Pakan Ruminansia pada Peternak Rakyat Di Kecamatan Rengat Barat.

Gay, L.R. 1976. Educational Research. Charles E. Merrill Publishing Company. Colombus. Ohio.

Haryanto, B, Ismeth I, IGM Budi, A dan Kusumo D. 2002. Panduan Teknis Sistem Integrasi Padi-Ternak. Badan Penelitian dan Pengembangan Pertanian. Departeman Pertanian

National Research Council. 1984. Nutrient Requirements of Beef Cattle, 6th rev. ed.Washington, D.C.: National Academy Press.

Neumann, A. L dan K. S Lusby. 1986. Matching Cow Productivity and Resources. Chapter 3. Beef Cattle (Eighth Ed.). Sapi Potong. John Wiley and Sons, Inc., New York. John Wiley and Sons, Inc, New York.

Syamsu J. A, 2006. Analisis Potensi Limbah Tanaman Pangan Sebagai Sumber Pakan Ternak Ruminansia di Sulawesi Selatan. Tesis. IPB. Bogor 